\title{
PENGEMBANGAN KOMUNITAS LOKAL SEKTOR EKONOMI PADA DESA NGLANGGERAN YOGYAKARTA
}

\author{
Indrawati \\ STID Al-Hadid, Surabaya \\ indrawati210275@gmail.com
}

\author{
Abdul Fatah Arif Hidayat \\ STID Al-Hadid, Surabaya \\ Abdulfataharifhidayat2@gmail.com
}

\begin{abstract}
Abstrak: Tulisan ini dilatarbelakangi oleh realitas fenomenal, keberhasilan sebuah desa yang miskin dan terbelakang, kemudian menjelma menjadi desa yang mandiri, kaya, dan berprestasi. Salah satu prestasinya adalah desa ini sukses mendapatkan predikat sebagai desa terbaik se-Asean. Dengan demikian, menarik untuk mengkaji bagaimana cara mereka melepaskan diri dari keadaan terbatas menjadi berdaya. Fokus tulisan ini mengkaji salah satu model intervensi komunitas yaitu pengembangan masyarakat lokal sektor ekonomi pada Desa Nglanggeran Yogyakarta. Tulisan ini menggunakan metode library research. Teori yang digunakan adalah teori model intervensi komunitas Rothman-Tropman spesifik model pengembangan masyarakat lokal. Hasil kajian menunjukkan bahwa model pengembangan komunitas lokal pada desa ini memiliki karakteristik yang unik, yaitu segala sumber daya (baik yang bersumber dari internal dan eksternal masyarakat) tidak ada yang luput dari perhatian mereka untuk dimanfaatkan potensinya. Sumber daya yang telah mereka potensikan antara lain sumber daya alam, sumber daya manusia, sumber daya sosial (kearifan lokal, spiritual, dan lain-lain). Termasuk mengajak kerja sama seluruh elemen sosial eksternal, antara lain lembaga pendidikan, lembaga penelitian, pemerintah, swasta, dan lain-lain. Terakhir, yang terpenting agar bisa mengoptimalkan segala sumber daya dalam rangka mencapai tujuan, hampir secara keseluruhan anggota masyarakat Nglanggeran terlibat dalam mengambil keputusan untuk menentukan apa yang terbaik bagi mereka.
\end{abstract}

Kata Kunci: Model intervensi komunitas, pengembangan komunitas lokal, Nglanggeran Yogyakarta

\begin{abstract}
This discourse is grounded in a phenomenon about a poor and underdeveloped village that succeeded in turning into a rich, independent, and highachieving village. One of its achievements was that the village was regarded as the best ASEAN village. Therefore, it is interesting to study how this village escaped from limited condition into an empowered one. This study focuses on studying one of community intervention models, namely locality development in the economic sector in Nglanggeran's village Yogyakarta. It applies library research method. It uses Rothman-Tropman's community intervention model theory, specifically the locality development model. The result shows that the locality development model in this village had a unique characteristic, namely all potential resources (derived from both internal and external resources to the community) were of concern to be used. They used natural, human, and social resources (local wisdom, spiritual, and so on). They also cooperated with all external social elements, such as educational institutions, research center, government, private parties, and so forth. Finally, almost all of Nglanggeran's community members were involved in deciding what the best way for them to optimize all resources to reach the goal.
\end{abstract}

Keywords: Community Intervention Model, Locality Development, Nglanggeran Yogyakarta 


\section{Pendahuluan}

Saat ini kemiskinan yang terjadi di Indonesia tergolong masih tinggi. Dilihat dari kondisi Indonesia pada Maret 2019 terdapat penduduk miskin berjumlah 25,14 juta atau 9,41 persen. ${ }^{1}$ Jika dipecah menurut wilayah perkotaan dengan desa maka jumlah penduduk miskin perkotaan pada Maret 2019 sebanyak 9,99 juta atau 6,69 persen dan jumlah penduduk miskin, pedesaan sebanyak 15,15 juta atau 12,85 persen. Kemiskinan tersebut diukur dengan garis kemiskinan sebesar Rp 425.250,/kapita/bulan pada Maret 2019. ${ }^{2}$

Salah satu fenomena kemiskinan sebagaimana hal di atas bisa ditemukan di Desa Nglanggeran, Kabupaten Gunung Kidul, D.I. Yogyakarta, Jawa Tengah. Desa ini dikenal sebagai desa yang gersang, apalagi saat musim kemarau akan bertambah parah. ${ }^{3}$ Kegersangan tanah di sekitar desa tersebut, mengakibatkan penduduk sulit bercocok tanam antara lain tanaman pokok seperti padi, jagung, sayur mayur, dan sebagainya. Padahal secara mayoritas pekerjaan mereka adalah bertani. Dalam kondisi tanah yang gersang, tanaman yang bisa bertahan hidup hanyalah singkong, sehingga wajar mereka menggunakan singkong sebagai pengganti beras yang sulit mereka dapatkan. Dengan demikian, wajar

\footnotetext{
${ }^{1}$ Berita Resmi Statistik, "Persentase Penduduk Miskin Maret 2019 Sebesar 9,41 Persen," Badan Pusat Statistik, diakses 3 Agustus 2019, https://www.bps.go.id/pressrelease/2019/07/15/1629/p ersentase-penduduk-miskin-maret-2019-sebesar-9-41persen.html

2 Ibid.

3 Chandra Iswinarno dan Muhammad Ilham Baktora, "Kemarau Panjang, 15 Kecamatan di Gunungkidu Terdampak Kekeringan," suarajogja.id, diakses November 2019.

https://jogja.suara.com/read/2019/11/05/160610/kema rau-panjang-15-kecamatan-di-gunungkidul-terdampakkekeringan?page $=1$.
}

penduduk desa ini dililit oleh masalah kemiskinan.

Salah satu tokoh masyarakat setempat menyampaikan "Kondisi alam yang ganas itu berdampak pada perekonomian masyarakat. Umumnya, warga di sini kondisinya miskin. Jangankan untuk menyekolahkan anak sampai ke jenjang perguruan tinggi, untuk sampai ke SMP atau SMA saja sudah sulit. Bahkan, guna mencukupi kebutuhan sehari-hari saja berat. Makanan penduduk juga sangat sederhana, sebagian nasi tetapi seringnya tiwul. Tiwul adalah makanan pokok warga Gunung Kidul waktu dulu yang terbuat dari bahan singkong." ${ }^{4}$ Keadaan ini bertambah sulit, karena letaknya yang cukup jauh dari ibukota D.I. Yogyakarta, yakni sejauh 25 $\mathrm{km} .{ }^{5}$ Melihat desanya tidak punya prospek ekonomi, akhirnya penduduk desa, terutama kalangan pemudanya memilih meninggalkan desa untuk merantau, bekerja di kota, atau menjadi TKI untuk mencari penghidupan yang lebih baik. $^{6}$

Melihat musibah kekeringan ekstrem di atas, mereka mulai bergerak untuk mengadakan usaha penanaman kembali atau penghijauan di desanya termasuk kawasan Gunung Api Purba Nglanggeran yang dipelopori tokoh-tokoh pemuda desa yang tergabung dalam Karang Taruna

\footnotetext{
${ }^{4}$ Liliek Dharmawan, "Berhenti Jadi Penebang Menjadi Penyelamat Lingkungan," Media Indonesia, diakses 26 Oktober 2018 https://mediaindonesia.com/read/detail/74124berhenti-jadi-penebang-menjadi-penyelamatlingkungan.html.

${ }^{5}$ Firmansah, "Desa Wisata Nglanggeran sebagai Destinasi Wisata Berbasis Ekowisata di Yogyakarta", Domestic Case Study, Sekolah Tinggi Pariwisata Ambarukmo Yogyakarta,

${ }^{6}$ Liliek Dharmawan, "Berhenti Jadi penebang Menjadi Penyelamat Lingkungan."
} 
Putera Bukit Mandiri. Usaha ini mereka tularkan kepada anggota yang lain, bahkan para anggota mendapat misi agar menyampaikan ke orang tua masing-masing agar tidak menebang pohon secara sembarangan untuk keperluan apa pun, termasuk dijual. ${ }^{7}$ Dari gerakan penghijauan tersebut, akhirnya mereka mendapat hibah dari Gubernur Jawa Tengah berupa uang yang diperuntukkan membangun desanya. Atas dasar kesepakatan bersama, uang tersebut dialokasikan untuk membuat bendungan mini/bendungan buatan yang berfungsi untuk mengairi pertanian dan perkebunan milik mereka. ${ }^{8}$ Keputusan mengalokasikan dana hibah untuk membuat bendungan mini didasari oleh masalah kekeringan hebat yang sering melanda desa pada musim kemarau. Dengan adanya bendungan yang menampung air hujan, kebutuhan air yang sangat vital bagi perkebunan buah dan sawah dapat terpenuhi pada musim kemarau sekalipun.

Setelah pegunungan nampak menghijau, salah satu tokoh pemuda desa tersebut, yaitu Sugeng Handoko seorang alumnus Jurusan Teknik Industri, Universitas Ahmad Dahlan Yogyakarta mencetuskan ide pembuatan Ekowisata Gunung Api Purba Nglanggeran. 9 Pemuda ini telah memelopori berbagai kegiatan positif di desanya, dari gagasan penghijauan, pembuatan embung, hingga usulan menjadikan Desa Nglanggeran menjadi

\footnotetext{
${ }^{7}$ lbid.

8 Shela Kusumaningtyas, "Kiprah Sugeng Handoko, Penggerak di Balik Ekowisata Desa Nglanggeran," Kompas.com, diakses 25 Januari 2018. https://sains.kompas.com/read/2018/05/04/200700623 /kiprah-sugeng-handoko-penggerak-di-balik-ekowisatadesa-nglanggeran?page=all

9 Luthfi Nurwafi Fatchurrohman, "Institutional Entrepreneurship Pemuda Dalam Mengembangkan Pokdarwis Desa Wisata Nglanggeran," Jurnal Studi Pemuda vol.4, no.2, (2015): 284.
}

Desa Ekowisata Gunung Api Batu Purba Nglanggeran. Atas hasil jerih payahnya, akhirnya ia mendapatkan berbagai penghargaan dari lembaga swasta dan pemerintah, antara lain: Pejuang Air dari Perusahaan air minum kemasan-Ades. ${ }^{10}$ la juga mendapatkan penghargaan Pemuda Pelopor Tingkat Nasional 2011 dalam bidang seni budaya dan pariwisata, Youth Change Maker 2011, Juara 1 Kader Konservasi D.I. Yogyakarta 2013, Pelaku PNPM Mandiri Terbaik 2014 oleh Kemenkokesra, dan pemenang Hi-lo Green Leader 2015. ${ }^{11}$

Usaha mengubah desanya menjadi Desa Ekowisata Gunung Api Purba Nglanggeran tidak mudah. Dimulai dari tahun 1999, mereka memulai penghijauan. Agar para penduduk tidak menebang pohon sembarangan yang bisa mengakibatkan usaha penghijauan mereka sia-sia, akhirnya tiap anggota karang taruna harus menyampaikan pesan moral kepada orang tuanya agar tidak menebang pohon lagi sebagai mata pencahariannya. Belum lagi cibiran dari beberapa anggota masyarakat yang menganggap mereka anak kemarin sore. Jalan terjal pun mereka lalui agar masyarakat mau bersama-sama menyatukan langkah untuk membangun desanya melalui sektor pariwisata yang dapat meningkatkan taraf hidup ekonomi mereka.

\footnotetext{
${ }^{10}$ Elise Dwi Ratnasari, "Kisah Sugeng Handoko, 'Pejuang Air' Gunung Kidul," CNN Indonesia, diakses 1 agustus 2020. https://www.cnnindonesia.com/gayahidup/20180507101350-282-296195/kisah-sugenghandoko-pejuang-air-gunung-kidul.

11 "Sosok Inspirasi, Sugeng Handoko Ubah Desa Tereksploitasi Menjadi Ekowisata," Gerakan Nasional Revolusi Mental, diakses 1 Agustus 2020. https://revolusimental.go.id/pers/sosok-inspirasi-sugenghandoko-ubah-desa-tereksploitasi-menjadi-ekowisata.
} 
Agar bisa menjadi desa ekowisata pun, mereka harus melalui tahapan yang panjang, mulai dari membaca potensi. Menurut mereka tahapan pertama, membaca potensi desa mereka tidak mudah, sebab hal-hal yang mereka lihat sehari-hari dianggap sebagai hal biasa sehingga tidak mudah membangkitkan inspirasi warga untuk memanfaatkannya sebagai sumber penghasilan ekonomi. ${ }^{12}$ Kedua, ketika ditemukan inspirasi tersebut Ekowisata Gunung Api Purba Nglanggeranmereka menyatukan gerak langkah para warga desa agar bersama-sama mendukung inovasi tersebut. Menurut Sugeng Handoko, butuh 3-4 tahun untuk mengelola SDM hingga bisa bersama-sama, bersatu padu membangun desa mereka melalui ekowisata. ${ }^{13}$ Ketiga, melakukan komunikasi keluar, menurut Sugeng Handoko, sebagus apa pun potensi kita, kalau kita tidak pernah mengomunikasikan diri kita keluar (pemasaran), maka tidak ada artinya apa yang telah kita miliki tersebut. ${ }^{14}$ Berkat kegigihan mereka, maka usaha yang dilakukan oleh Sugeng Handoko dan kawankawannya dari waktu ke waktu akhirnya dapat dinyatakan sangat sukses. Terbukti dari tahun ke tahun terjadi kunjungan wisatawan yang meningkat demikian pesat. $^{15}$

Berdasarkan data yang diperoleh dari BPS Kabupaten Gunungkidul dalam kurun waktu enam tahun terakhir, jumlah wisatawan

\footnotetext{
12 "Sugeng Handoko: Peran Pemuda Membangun DesaBuka Talks," Video YouTube, 20:29, dikirim oleh "Bukalapak," Juni 6, 2018 https://youtu.be/dxvv0OTOG7k.

13 lbid.

14 Ibid.

15 Ismi Atikah Jamalina dan Dyah Titis Kusuma Wardani, "Strategi Pengembangan Ekowisata Melalui Konsep Community Based Tourism (CBT) dan Manfaat Sosial dan Ekonomi Bagi Masyarakat di Desa Wisata Nglanggeran,
}

meningkat sebanyak $40-60 \%$, antara lain: pada tahun 2011: 616.696, tahun 2012: 1.000.387, kemudian pada tahun 2013 meningkat menjadi 1.337 .438 , meningkat lagi pada tahun 2014 menjadi 1.955.817, dan berikutnya pada tahun 2015 peningkatannya menjadi signifikan, menjadi 2.642.759. ${ }^{16}$ Hasil jerih payah mereka akhirnya berbuah manis dengan mendapatkan penghargaan ASEAN Community Bases Tourism Award (ASEAN CBT Award). Kriteria penilaian di atas sesuai dengan standar CBT (Community Based Tourism), yaitu dinilai berhasil menerapkan prinsip-prinsip pengelolaan pariwisata berbasis masyarakat. Adapun kriteria utama penilaian ASEAN CBT, antara lain: kepemilikan dan pengelolaan oleh masyarakat, serta berkontribusi terhadap kesejahteraan masyarakat dan pelestarian alam sekitar. ${ }^{17}$

Berdasarkan atas data-data yang telah dihimpun, dijumpai beberapa indikator yang menunjukkan bahwa usaha yang dilakukan oleh Pokdarwis dapat dikatakan sebagai usaha intervensi komunitas dengan model/tipe pengembangan masyarakat lokal. Intervensi pengembangan masyarakat lokal adalah salah satu model usaha menciptakan kemajuan sosial dan ekonomi masyarakat (pemberdayaan) dengan cara menekankan partisipasi aktif serta inisiatif anggota masyarakat itu

Patuk, Gunung Kidul," Jurnal Ekonomi dan Studi Pembangunan vol. 18, no. 1 (2017): 71-85.

16 "Jumlah Wisatawan, Hotel dan Pariwisata," BPS Kabupaten Gunung Kidul, diakses 28 Agustus 2019.https://gunungkidulkab.bps.go.id/galery.html\#\# 17 "DESA WISATA NGLANGGERAN MEMPEROLEH PEGHARGAAN CBT ASEAN DI SINGAPORE," GAP, 20 Januari 2017. http://gunungapipurba.com/posts/detail/desa-wisatanglanggeran-memperoleh-peghargaan-cbt-asean-disingapore 
sendiri. 18 Adapun indikator model pengembangan masyarakat lokal desa ini dapat dijumpai bahwa masyarakat menjadi pihak utama dan aktif dalam mengambil keputusan atas apa yang terbaik untuk desa ekowisata mereka, lewat forum rutin selapanan (35 hari sekali) mereka bermusyawarah untuk membahas ide-ide demi kemajuan desa ekowisata mereka, mereka yang mengusulkan, dan mereka sendirilah yang mengerjakan keputusan yang mereka buat tersebut. Sehingga pada intinya, strategi perubahannya menekankan pada usaha melibatkan partisipasi masyarakat secara menyeluruh, baik dari sisi sumber daya alam, manusia, fisik, lingkungan eksternal, dan lain-lain.

Pengembangan masyarakat lokal itu sendiri merupakan bagian dari salah satu model intervensi komunitas milik Rothman dan Tropman. Adapun pemilihan teori di atas karena teori ini kompatibel untuk membantu menjelaskan fokus kajian dari tulisan ini. Sebagaimana Rothman dalam Isbandi menyebutkan bahwa intervensi komunitas adalah upaya untuk memperbaiki keberfungsian sosial pada komunitas sasaran perubahan. ${ }^{19}$ Intervensi komunitas juga bisa diartikan sebagai kegiatan yang bertujuan membangun kapasitas komunitas sasaran dalam memenuhi kebutuhan dasarnya secara mandiri.

Pengembangan komunitas lokal merupakan satu dari tiga model intervensi komunitas yang dikenal selama ini. Dua lainnya yaitu: model perencanaan sosial dan aksi sosial.

18 Edi Soeharto, Membangun Masyarakat Memberdayakan Rakyat Kajian Strategis Pembangunan Kesejahteraan Sosial dan Pekerjaan Sosial (Bandung: Refika Aditama, 2014), 42.
Sedangkan model pengembangan masyarakat lokal diartikan sebagai usaha intervensi yang menitikberatkan pada strategi melibatkan secara menyeluruh partisipasi masyarakat dalam memproses dan mempotensikan aset-aset lokalnya, baik dari segi sumber daya manusia, sumber daya alam, sumber daya fisik, dan sebagainya untuk kepentingan kemakmuran masyarakat itu sendiri. ${ }^{20}$ Kesuksesan Karang Taruna Putera Bukit Mandiri dalam mengembangkan komunitas lokal desanya menarik untuk dikaji. Kaum akademisi, peneliti, dan aktivis pengembangan masyarakat Islam dapat belajar mengenai kisah keberhasilan yang ditunjukkan oleh sepak terjang para pemuda Desa Nglanggeran yang bahu membahu dengan elemen warga desa lainnya dalam memecahkan persoalan kemiskinan dan kerusakan alam yang meraka hadapi. Dengan belajar dari kesuksesan mereka akan ditemukan berbagai pelajaran mengenai variabel keberhasilan memberdayakan masyarakat desa.

Sugeng Handoko sendiri merasa beruntung bahwa ia bisa belajar di Fakultas Teknik Universitas Ahmad Dahlan (sekarang ini sudah alumnus). Kampus yang berbasis Islam itu banyak memberikan ilmu tentang bagaimana cara memaknai hidup. Melalui mata kuliah yang diberikan, khususnya mata kuliah tentang ilmu keislaman. "Di UAD nilai keislaman lebih ditonjolkan lewat mata kuliah sertifikasi 1 sampai 4 dan studi Islam. Saya sepakat, orang sukses itu bukan orang kaya raya atau banyak harta, tapi

\footnotetext{
${ }^{19}$ Isbandi Rukminto Adi, IImu Kesejahteraan Sosial dan Pekerjaan Sosial: Pengantar pada Pengertian dan Beberapa Pokok Bahasan (Depok: FISIP UI PRESS, 2005), 141-150.

${ }^{20}$ Ibid., 87.
} 
orang yang dapat memberikan banyak manfaat pada banyak orang." Nilai-nilai itu yang dipegang untuk dapat memajukan pariwisata di Gunung Api Purba. ${ }^{21}$

Adapun fokus tulisan ini mengkaji penerapan model pengembangan masyarakat lokal sektor ekonomi pada Desa Nglanggeran, Kecamatan Patuk, Kabupaten Gunung Kidul, D.I. Yogyakarta. Komunitas lokal yang dimaksud tidak lain adalah warga Desa Nglanggeran sendiri yang mayoritas beragama Islam. Dalam web resmi Kelurahan Nglanggeran, Kecamatan Patuk, Kabupaten Gunung Kidul disampaikan sebagai berikut: "dalam aktivitas keseharian, masyarakat Desa Nglanggeran sangat taat dalam menjalankan ibadah keagamaan. Setiap Rukun Tetangga (RT) dan Padukuhan memiliki kelompokkelompok pengajian, di Padukuhan Gunungbutak ada yasinan keliling tingkat RT tiap malam jum'at. Pada peringatan hari besar Islam, penduduk Desa Nglanggeran kerap menggelar acara peringatan dengan Kenduri, dan dalam agenda Bersih Dusun/Desa ada kirab budaya dengan tema yang disesuaikan dengan tema yang disepakati bersama." 22 Sebagian besar warga Desa Nglanggeran beragama Islam. Dengan rincian sebagai berikut: dari total populasi penduduk yang berjumlah 2.629 orang, sebanyak $97,91 \%$ merupakan warga beragama Islam (2.574), sisanya 0,46\% beragama Kristen, $1,67 \%$ beragama Katholik, dan lain-lainnya $0 \% .{ }^{23}$ Adapun

21 Warta Utama UAD, “Alumni FTI Ini Sukses Menggerakkan Masyarakat Sadar Akan Ekowisata Gunung Api Purba," Universitas Ahmad Dahlan, diakses 2 Agustus $2020 . \quad$ https://uad.ac.id/id/alumni-fti-ini-suksesmenggerakkan-masyarakat-sadar-akan-ekowisatagunung-api-purba/

22 Pemerintah Desa Nglanggeran, Kecamatan Patuk, Kabupaten Gunungkidul Tahun 2013, “Profil Masyarakat tujuan dari studi ini adalah mendeskripsikan penerapan model pengembangan masyarakat lokal sektor ekonomi pada Desa Nglanggeran, Kecamatan Patuk Kabupaten Gunungkidul, D.I. Yogyakarta yang dilakukan oleh Kelompok Sadar Wisata Nglanggeran.

Disadari bahwa kajian-kajian mengenai intervensi komunitas sudah banyak dilakukan, namun tidak semua kajian di atas disusun untuk mengetahui karakteristik keunikan dari masing-masing model intervensi komunitas. Sehingga dengan demikian diharapkan melalui studi ini, dapat memberikan manfaat dalam memperkaya khazanah literatur/wawasan tentang penerapan model pengembangan masyarakat lokal sektor ekonomi di Nglanggeran. Dengan mengetahui keunikan pengembangan masyarakat lokal pada desa ini dapat dipahami bahwa usaha pengembangan masyarakat lokal pada tiap desa memiliki kekhasan/perbedaan antara desa satu dengan desa lainnya, sehingga strategi perubahan yang berhasil digunakan pada desa tersebut belum tentu bisa diterapkan pada desa lain, kecuali strategi yang bernilai prinsipil saja.

Adapun studi terdahulu tentang intervensi komunitas antara lain: Intervensi Pengembangan Masyarakat Melalui Model Pengelolaan Pesisir Karangsong Kabupaten Indramayu karya Siti Faoziyah. ${ }^{24}$ Persamaan studi ini dengan studi Faoziyah adalah pada

Desa" Kalurahan Nglanggeran, diakses 6 Juli 2020, https://www.nglanggeran-patuk.desa.id/first/artikel/34. 23 "Statistik Berdasar Agama," Kalurahan Nglanggeran, diakses Juli 6, 2020, https://www.nglanggeranpatuk.desa.id/first/statistik/agama.

24 Siti Faoziyah, "Intervensi Pengembangan Masyarakat Melalui Model Pengelolaan Pesisir Karangsong Kabupaten Indramayu," ICSW: International Conference on Social Work (2020): 1-21. 
subjek kajiannya, yaitu sama-sama mengkaji salah satu model intervensi komunitas yaitu pengembangan komunitas lokal, namun perbedaannya adalah pada pendekatan dan objek yang dikaji, pada studi ini mengkaji intervensi komunitas dengan pendekatan satu model yaitu pengembangan komunitas lokal pada Desa Nglanggeran, dan kajian Faoziyah mengkaji intervensi komunitas dengan dua pendekatan yaitu pengembangan masyarakat lokal dan aksi sosial pada Desa Pesisir Karangsong Kabupaten Indramayu.

Studi intervensi komunitas pengembangan masyarakat lokal dapat juga dijumpai pada jurnal ilmiah dengan judul "Analisis Resiko Implementasi Kegiatan Pengembangan Masyarakat Sekitar Hutan di Sumetera Barat" karya Ferdinal Asmin. ${ }^{25}$ Persamaan dengan kajian karya Asmin yaitu sama-sama mengkaji model intervensi komunitas yaitu pengembangan masyarakat lokal, namun perbedaannya ada pada subjek dan objek kajiannya, yaitu dalam artikel tersebut subjek yang diteliti adalah analisis resiko atas penerapan model intervensi pengembangan masyarakat lokal, sedangkan kajian dari artikel ini adalah deskripsi penerapan model pengembangan masyarakat lokal. Sedangkan objek kajiannya juga berbeda, artikel ini mengangkat objek kajiannya Desa Nglanggeran, sedangkan pada artikel tersebut objek kajiannya masyarakat sekitar hutan Sumatera Barat. Studi intervensi komunitas yang lain dapat ditemukan pada artikel dengan judul Penerapan Teknologi

${ }^{25}$ Ferdinal Asmin, "Analisis Resiko Implementasi Kegiatan Pengembangan Masyarakat Sekitar Hutan di Sumetera Barat," Jurnal Sistemasi: Sistem Informasi vol. 8, no. 1 (2019): 194-203.

${ }^{26}$ Ellya Susilowati, "Penerapan Teknologi Pengembangan Masyarakat Pada Program Desa Sabilulungan,"
Pengembangan Masyarakat Pada Program Desa Sabilulungan. ${ }^{26}$ Sama pula dengan kajian ini, mengangkat penerapan model intervensi pengembangan masyarakat lokal, namun yang membedakannya adalah objek kajiannya saja. Berdasarkan studi terdahulu tersebut, kajian mengenai pengembangan masyarakat lokal pada desa nglanggeran belum pernah dilakukan sebelumnya, hal itu menjadikan studi ini berbeda dan baru untuk dikaji.

Metode kajian yang digunakan adalah metode library research, yaitu metode kajian suatu realitas dengan menggunakan pustaka/literatur sebagai sumber utama dalam mengkaji realitas tersebut. 27 Sedangkan sumber data yang digunakan dalam kajian ini antara lain: jurnal ilmiah tentang pengembangan dan dampak kepariwisataan Gunung Api Purba Nglanggeran, official website: nglanggeranpatuk.desa.id, Gunung Api Purba.com., BPS Kabupaten Gunung Kidul 2017, situs YouTube Gunung Api Purba Nglanggeran, dan lain-lain.

\section{Model Intervensi Komunitas Menurut Rothman dan Tropman}

Model intervensi komunitas dicetuskan oleh Rothman dan Tropman ada tiga macam, antara lain model perencanaan sosial, pengembangan masyarakat lokal, dan aksi sosial. Ketiganya bisa dibedakan melalui 12 variabel, antara lain: (1) tujuan tindakan intervensi terhadap masyarakat; (2) asumsi mengenai struktur komunitas dan kondisi masalahnya; (3) strategi dasar

LINDAYASOS: Jurnal IImiah Perlindungan \& Pemberdayaan Sosial, vol. 1, no. 1 (2019): 16-31.

${ }^{27}$ Rachmat Kriyantono, Teknik Praktis Riset Komunikasi : Disertai Contoh Praktis Riset Media, Public Relation, Advertising, Komunikasi Organisasi, Komunikasi Pemasaran (Jakarta: Kencana Prenada Media, 2010), 246. 
dalam melakukan perubahan; (4) ciri-ciri taktik dan teknik perubahannya; (5) peran praktisi yang menonjol; (6) media perubahan; (7) orientasi terhadap struktur kekuasaan; (8) batasan definisi penerima layanan; (9) asumsi mengenai kepentingan dari kelompok; (10) konsepsi mengenai kepentingan dari kelompok; (11) konsepsi mengenai penerima layanan; (12) konsepsi mengenai peran penerima layanan. ${ }^{28}$

Adapun pengembangan masyarakat lokal, bisa dipahami sebagai berikut: ${ }^{29}$ pertama, tujuan intervensi terhadap komunitas. Model pengembangan masyarakat lokal bertujuan mengembangkan kapasitas masyarakat dan pengintegrasian unsurunsur sosial masyarakat, antara lain potensi alam, SDM, finansial, sosial, budaya, tokoh masyarakat, lembaga/kelompok sosial, jaringan sosial, dan lain-lain. Oleh karena tujuannya demikian maka subjek pengembang lebih menekankan process goal daripada task goal. Artinya subjek intervensi senantiasa menstimulasi kelompok sasaran/komunitas yang diberdayakan untuk aktif terlibat dalam tiap proses/tahapan pembangunan, mulai dari perencanaan, pelaksanan, monitoring pelaksanaan pembangunan, dan evaluasinya. Kedua, kategori struktur komunitas dan kondisi permasalahan yang digunakan oleh subjek adalah mengatasi seluruh persoalan yang dialami oleh komunitas dalam wilayah geografi tertentu, dan bukan terbatas pada segmen penduduk yang mengalami masalah tertentu.

Ketiga, strategi dasar dalam melakukan perubahan dalam model pengembangan

\footnotetext{
28 Isbandi Rukminto Adi, Intervensi Komunitas dan Pengembangan Masyarakat sebagai Upaya
}

masyarakat lokal, sangat menekankan keterlibatan warga masyarakat sendiri dalam mengambil keputusan atas masalah yang mereka hadapi (process goal). Subjek pemberdaya akan melibatkan perwakilan masyarakat seluas mungkin dalam menentukan pemecahan masalah yang mereka hadapi. Keempat, dalam mengimplementasikan strategi tersebut, maka membutuhkan taktik dan teknik tertentu dalam mengubah masyarakat yang semula miskin, tak berdaya menjadi berdaya. Dalam model pengembangan masyarakat, oleh karena strateginya process goal, maka taktiknya mengandalkan proses diskusi untuk pencapaian kesepakatan dari berbagai unsur pihak masyarakat, misal: antara tokoh masyarakat, tokoh pemuda, warga masyarakat yang tergabung dalam berbagai unsur perwakilan, misalnya petani, pedagang, ibu-ibu PKK, dan lain-lain.

Kelima, dengan demikian, agar mewujudkan strategi dan taktik perubahan di atas, maka peran agent of change atau praktisi yang menonjol pada model pengembangan masyarakat lokal adalah sebagai fasilitator dan pemungkin (enabler) yang mendukung masyarakat agar berproses memiliki kapasitas dalam merealisasikan kebutuhan-kebutuhan mereka, atau memecahkan masalahmasalah mereka. Keenam, oleh karena itu, maka media perubahannya dikenal menggunakan kelompok-kelompok diskusi yang berfungsi sebagai media atau sarana merumuskan masalah, pemecahan masalah, misalnya: agar masyarakat dapat menentukan mengambil keputusan 
tindakan apa yang harus diambil, sangat ditentukan pemahaman masyarakat atas masalah-masalah yang mereka hadapi, aset-aset apa saja yang mereka miliki, dan lan-lain, sehingga masyarakat bisa memutuskan pemecahan apa yang terbaik. Hal di atas dapat dicapai, jika ada kelompokkelompok diskusi kecil yang bisa memediasi tumbuhnya pemahaman-pemahaman masyarakat atas masalahnya. Ketujuh, orientasi terhadap struktur kekuasaan, pada model pengembangan masyarakat lokal sebaliknya, pihak berwenang diposisikan sebagai partner/kolaborator yang bekerja bersama-sama memecahkan masalah yang dihadapi oleh komunitas lokal tersebut.

Kedelapan, dalam intervensi komunitas, kelompok sasaran yang diberdayakan memang terdiri dari dua bentuk komunitas, yaitu komunitas yang terikat dalam wilayah geografis tertentu, bisa juga dalam bentuk segmen komunitas tertentu yang samasama memiliki masalah khusus, misal pemberdayaan masyarakat khusus difabel. Bentuk pertama inilah yang dikenal dalam model pengembangan masyarakat lokal, kelompok sasaran yang ditanganinya terikat dalam satu kesatuan geografis yang berada di wilayah tertentu. Kesembilan, dalam melakukan intervensi komunitas, subjek pemberdaya akan berhadapan dengan berbagai macam kelompok-kelompok sosial yang memiliki potensi mendukung sehingga bisa menjadi partner/kolaborator/sponsor dalam usaha intervensi tersebut, ada juga kelompok yang berbeda kepentingan, yang mana kepentingan tersebut bisa berseberangan dengan usaha intervensi yang akan dilakukan pada komunitas tersebut. Model pengembangan masyarakat lokal, kelompok-kelompok yang ada dalam komunitas diajak kerja sama memecahkan masalah bersama-sama dengan dipandu oleh subjek pemberdaya terkait.

Kesepuluh, dalam model pengembangan masyarakat lokal, kelompok sasaran sebagai penerima layanan merupakan pihak sentral, penting, aset SDM yang berharga, masukan dan pendapatnya diperhitungkan, mereka dilibatkan secara penuh dalam merumuskan masalah dan pemecahannya. Kesebelas, dengan diasumsikan kelompok sasaran sebagai pihak sentral, penting, dan berharga, maka konsepsi peran penerima layanan adalah peran-peran yang aktif, partisipatif, baik dalam hal merumuskan masalah mereka sendiri, merumuskan pemecahannya/kebijakan untuk mereka sendiri, mereka bersama berusaha belajar dan mengembangkan diri mereka sendiri. Keduabelas, pemanfaatan intervensi komunitas pada model pengembangan masyarakat lokal adalah mengedukasi kemandirian masyarakat dalam menghadapi masalah, dan bahkan kemandirian dalam memecahkan masalah mereka sendiri. Sehingga dalam hal ini diharapkan dapat menciptakan kapasitas/kemampuan dalam memenuhi kebutuhan ekonominya, dengan sendirinya akan membangkitkan rasa percaya diri akan kemampuan masing-masing anggota masyarakat.

\section{Pengembangan Masyarakat Islam}

Masyarakat Islam adalah kelompok manusia yang mempunyai kebiasaan, tradisi, sikap dan perasaan persatuan yang diikat oleh kesamaan agama, yakni agama 
Islam. 30 Sedangkan pengembangan masyarakat Islam (Islamic Community Development) merupakan sebuah bentuk dakwah dengan sasaran semakin teberdayakan potensi-potensi yang ada di masyarakat. ${ }^{31}$ Senada dengan pengertian di atas, secara terminologi pengembangan masyarakat Islam (PMI) adalah sistem tindakan nyata yang menawarkan alternatif model pemecahan masalah ummah dalam bidang sosial, ekonomi, dan lingkungan dalam perspektif Islam. ${ }^{32}$

Perspektif Islam yang dimaksud dalam konteks PMI di atas adalah sasaran pengembangannya adalah individu muslim, atau komunitas muslim dengan orientasi pengembangan kualitas hidup individuindividunya. ${ }^{33}$ Dakwah PMI itu sendiri merupakan perwujudan tugas dan fungsi manusia sebagai khalifah fi al-ardh yang melekat sejak awal penciptaan manusia, yaitu dalam rangka menumbuhkan dan mewujudkan kesalehan individual dan kesalehan sosial. ${ }^{34}$

Selain pengembangan masyarakat Islam merupakah bagian dari usaha menjalankan misi khalifah fil ardh, pengembangan masyarakat Islam juga merupakan bagian dari dakwah bilhal yaitu dakwah dengan upaya untuk membangun daya, dengan cara mendorong, memotivasi, dan membangkitkan kesadaran akan potensi yang dimiliki serta berupaya untuk

\footnotetext{
30 Nanih Machendrawaty dan Agus Ahmad Safei, Pengembangan Masyarakat Islam dari Ideologi Strategi Sampai Tradisi (Bandung: Remaja Rosdakarya Bandung, 2001), 5.

${ }^{31}$ Mukhlis Aliyudin, "Pengembangan Masyarakat Islam Dalam Sistem Dakwah Islamiyah," IImu Dakwah Academic Journal for Homiletic Studies vol. 4, no. 14 (2009): 777-792.

${ }^{32}$ Amrullah Ahmad, "Strategi Dakwah Islam di Tengah Era Reformsi menuju Indonesia Baru dalam Memasuki Abad
}

mengembangkannya dengan dilandasi proses kemandirian. ${ }^{35}$

\section{Desa Ekowisata Gunung Api Purba Nglanggeran}

Nglanggeran merupakan Desa yang terletak secara administratif di Kecamatan Patuk, Kabupaten Gunungkidul, Daerah Istimewa Yogyakarta. Kawasan Ekowisata Gunung Api Purba memiliki luas 48 ha. Sedangkan wilayah Desa Nglanggeran memiliki luas 762 ha. Lahan Desa Nglanggeran sebagian besar digunakan untuk lahan pertanian, perkebunan, ladang dan pekarangan. Pola pemilikan tanah tersebut didominasi oleh tanah kas desa. Jarak Desa Nglanggeran dari ibukota kecamatan adalah $4 \mathrm{~km}, 20 \mathrm{~km}$ dari ibukota kabupaten dan berjarak $25 \mathrm{~km}$ dari ibukota D.I. Yogyakarta. Nglanggeran terdiri dari lima dusun yaitu Dusun Doga, Dusun Nglanggeran Kulon, Dusun Nglanggeran Wetan, Dusun Karangsari, dan Dusun Gunungbutak. Pusat pemerintahan desa terletak di Dusun Doga. ${ }^{36}$

Adapun pihak pengelola Desa Ekowisata Nglanggeran adalah Pokdarwis yang baranggotakan dari seluruh unsur Karang Taruna Putera Bukit Mandiri. Adapun visi Pokdarwais adalah menjadikan Kawasan Ekowisata Gunung Api Purba Nglanggeran sebagai kawasan wisata unggulan yang berwawasan lingkungan berbasis

ke-21," Makalah, Sarasehan Nasional: Menggagas Dakwah Menuju Indonesia Baru, SMF Dakwah IAIN Sunan Gunung Djati, Bandung, 21 April 1999.

${ }_{33}$ Machendrawaty dan Safei, Pengembangan Masyarakat Islam dari Ideologi Strategi sampai Tradisi, 29.

34 Ibid.

35 M. Ali Aziz, Ilmu Dakwah (Jakarta: Kencana, 2009), 378.

36 "Informasi Geografis," GAP, diakses 22 Juli 2019. http://gunungapipurba.com/pages/detail/informasigeografis. 
masyarakat. ${ }^{37}$ Sedangkan misinya: (1) meningkatkan SDM dan pengelolaan Kawasan Ekowisata Gunung Api Purba; (2) membangun dan meningkatkan kesadaran peduli lingkungan; (3) menggalang kemitraan dengan berbagai pihak yang berkompeten dalam masalah kepariwisataan dan aktivis peduli lingkungan; (4) melindungi lingkungan di Kawasan Ekowisata Gunung Api Purba, baik kebudayaan, flora, fauna, dan keunikan batuannya; (5) melibatkan masyarakat dalam proses perencanaan, pelaksanaan, pengawasan, dan perbaikan/evaluasi terhadap kinerja pengelolaan Kawasan Gunung Api Purba; (6) melakukan promosi secara efektif dan efisien; (7) meningkatkan lama tinggal wisatawan (length of stay) di Kabupaten Gunung Kidul dan Daerah Istimewa Yogyakarta. 38 Sedangkan tujuannya adalah meningkatkan kesejahteraan masyarakat dengan segala potensi alam dan budaya yang ada sekaligus menjaga kelestariannya. ${ }^{39}$

\section{Pengembangan Masyarakat Lokal Sektor Ekonomi pada Desa Nglanggeran Menuju Desa Ekowisata Gunung Api Purba Nglanggeran}

Pertama, usaha Sugeng Handoko bersama kawan-kawannya yang tergabung dalam Karang Taruna Putra Bukit Mandiri didorong oleh kondisi permasalahan yang dihadapi oleh komunitas lokal Desa Nglanggeran tersebut.

Masalah-masalah yang dihadapi oleh mereka, antara lain tingkat pendidikan komunitas lokal Nglanggeran masih tergolong rendah. Adapun penduduk Desa Nglanggeran berdasarkan tingkat pendidikannya, dapat dilihat sebagai berikut:

Tabel 1 - Data Kependudukan Desa Nglanggeran Berdasarkan Pendidikan

\begin{tabular}{|c|c|c|c|c|c|c|c|}
\hline \multirow[t]{2}{*}{ No } & \multirow[t]{2}{*}{ Kelompok } & \multicolumn{2}{|c|}{ Total } & \multicolumn{2}{|c|}{ Laki-Laki } & \multicolumn{2}{|c|}{ Perempuan } \\
\hline & & Jumlah & Prosentase & Jumlah & Prosentase & Jumlah & Prosentase \\
\hline 1 & Tamat SD/Sederajat & 689 & $26,21 \%$ & 338 & $12,86 \%$ & 351 & $13,35 \%$ \\
\hline 2 & SMP/Sederajat & 592 & $22,52 \%$ & 321 & $12,21 \%$ & 271 & $10,31 \%$ \\
\hline 3 & Tidak/Belum Sekolah & 545 & $20,73 \%$ & 233 & $8,86 \%$ & 312 & $11,87 \%$ \\
\hline 4 & SMA/Sederajat & 524 & $19,93 \%$ & 282 & $10,73 \%$ & 242 & $9,21 \%$ \\
\hline 5 & $\begin{array}{l}\text { Belum Tamat } \\
\text { SD/Sederajat }\end{array}$ & 207 & $7,87 \%$ & 112 & $4,26 \%$ & 95 & $3,61 \%$ \\
\hline 6 & Diploma IV/Strata 1 & 42 & $1,60 \%$ & 17 & $0,65 \%$ & 25 & $0,95 \%$ \\
\hline 7 & $\begin{array}{l}\text { Akademi/Diploma } \\
\text { III/S.Muda }\end{array}$ & 16 & $0,61 \%$ & 7 & $0,27 \%$ & 9 & $0,34 \%$ \\
\hline 8 & Diploma I/II & 11 & $0,42 \%$ & 3 & $0,11 \%$ & 8 & $0,30 \%$ \\
\hline 9 & Strata II & 0 & $0 \%$ & 0 & $0 \%$ & 0 & $0 \%$ \\
\hline 10 & Strata III & 0 & $0 \%$ & 0 & $0 \%$ & 0 & $0 \%$ \\
\hline \multicolumn{2}{|c|}{ Total } & 2569 & $100 \%$ & 1315 & 50,025 & 1314 & $49,96 \%$ \\
\hline
\end{tabular}

Sumber data: Statistik warga Desa Nglanggeran berdasarkan pendidikan, T.T. ${ }^{40}$

37 "Visi Misi dan Tujuan," GAP, diakses August 10, 2019. http://gunungapipurba.com/pages/detail/visi-misi-dantujuan.

38 Ibid.

39 lbid.
40 "Statisitik Berdasar Pendidikan," Kalurahan Nglanggeran, diakses Juni 25, 2020, https://www.nglanggeranpatuk.desa.id/first/statistik/pendidikan-dalam-kk. 
Ditinjau dari mata pencaharian, mayoritas penduduknya bermata pencaharian petani dengan jumlah orang baik yang menggarap lahan sendiri dan tidak sebesar 990 orang dari 2629 total populasi penduduk.

Tabel 2 - Data Kependudukan Desa Nglanggeran Berdasarkan Pekerjaan

\begin{tabular}{llcccccc}
\hline \multirow{2}{*}{ Ko } & \multirow{2}{*}{ Kelompok } & \multicolumn{2}{c}{ Total } & \multicolumn{2}{c}{ Laki-Laki } & \multicolumn{2}{c}{ Perempuan } \\
\cline { 3 - 8 } & & Jumlah & Prosentase & Jumlah & Prosentase & Jumlah & Prosentase \\
\hline 1 & Petani/Perkebunan & 799 & $30,39 \%$ & 366 & $13,92 \%$ & 433 & $16,47 \%$ \\
\hline 2 & Belum/Tidak bekerja & 507 & $19,28 \%$ & 257 & $9,78 \%$ & 250 & $9,51 \%$ \\
\hline 3 & Pelajar/Mahasiswa & 341 & $12,97 \%$ & 188 & $7,15 \%$ & 153 & $5,82 \%$ \\
\hline 4 & $\begin{array}{l}\text { Mengurus rumah } \\
\text { tangga }\end{array}$ & 271 & $10,31 \%$ & 0 & $0,00 \%$ & 271 & $10,31 \%$ \\
\hline 5 & Karyawan swasta & 242 & $9,21 \%$ & 152 & $5,78 \%$ & 90 & $3,42 \%$ \\
\hline 6 & Buruh harian lepas & 191 & $7,27 \%$ & 139 & $5,29 \%$ & 52 & $1,96 \%$ \\
\hline 7 & Wiraswasta & 184 & $7,00 \%$ & 149 & $5,67 \%$ & 35 & $1,33 \%$ \\
\hline 8 & $\begin{array}{l}\text { Pegawai Negeri Sipil } \\
\text { (PNS) }\end{array}$ & 30 & $1,14 \%$ & 19 & $0,72 \%$ & 11 & $0,42 \%$ \\
\hline 9 & Perangkat Desa & 13 & $0,49 \%$ & 8 & $0,30 \%$ & 5 & $0,19 \%$ \\
\hline 10 & Sopir & 10 & $0,38 \%$ & 10 & $0,38 \%$ & 0 & $0,00 \%$ \\
\hline Total & $\mathbf{2 5 6 9}$ & $\mathbf{1 0 0 \%}$ & $\mathbf{1 3 1 5}$ & $\mathbf{5 0 , 0 2 5}$ & $\mathbf{1 3 1 4}$ & $\mathbf{4 9 , 9 6 \%}$ \\
\hline
\end{tabular}

Sumber data: Statistik warga Desa Nglanggeran berdasarkan pekerjaan, t.t. $^{41}$

Namun sebagai petani, mereka memiliki nasib yang kurang beruntung karena kondisi alam Desa Nglanggeran (sebelum ekowisata digagas), sangat kering/gersang. Akibatnya tidak banyak tanaman yang bisa ditanam dalam kondisi tanah seperti itu. Hanya tanaman singkong yang bisa ditanam. Tanaman pokok dan kebutuhan sehari-hari, seperti padi, sayur mayur, sukar bertahan dalam keadaan tanah Nglanggeran yang kering kerontang.

Kekeringan ini disebabkan oleh Nglanggeran berada di daerah cekungan ekstrem, dan diperparah oleh perilaku penduduk setempat yang senantiasa menebang pohon-pohon untuk bahan bakar, dan ada juga yang memang sengaja menebang untuk dijual. ${ }^{42}$ Selain pohon, penduduk setempat mengeksplorasi bebatuan untuk dijual juga. ${ }^{43}$ Pengambilan tersebut bisa mencapai 2 truk rencek atau potong-potongan kayu kering setiap pekannya. Hasil potongan tersebut akan dijual ke Piyungan, Kabupaten Bantul. ${ }^{44}$ Kondisi kekeringan bertambah parah lagi bila musim kemarau datang.

Dapat disimpulkan, dengan keadaan tanah seperti itu, perekonomian penduduk Nglanggeran yang mayoritas petani akhirnya mengalami keterpurukan. Dampak lebih lanjut, mereka tidak mampu menyekolahkan anak sampai ke jenjang SMP atau SMA, apalagi sampai jenjang ke perguruan tinggi. Untuk memenuhi

\footnotetext{
41 "Statistik Berdasar Pekerjaan," Kalurahan Nglanggeran, diakses Juni 25, 2020, https://www.nglanggeranpatuk.desa.id/first/statistik/pekerjaan.

42 "Sugeng Handoko: Peran Pemuda Membangun Desa-Buka Talks," Video YouTube, 20:29, dikirim oleh "Bukalapak," Juni 6, 2018. https://youtu.be/dxvv0OTOG7k .

${ }^{43}$ Ibid.

${ }^{44}$ Liliek Dharmawan, "Berhenti Jadi penebang Menjadi Penyelamat Lingkungan."
} 
kebutuhan makan sehari-hari saja berat, sehingga membuat masyarakat memanfaatkan singkong yang mudah ditanam untuk kebutuhan makan seharihari atau dijadikan makan pokok. Singkong ini diolah masyarakat untuk dijadikan makanan tiwul. ${ }^{45}$ Sebagai akibat rendahnya sumber penghidupan di desa, maka para pemuda lebih memilih merantau ke kota untuk mencari pekerjaan. Mereka mengadu nasib ke Jakarta, Batam, Kalimantan, dan lain-lain. ${ }^{46}$

Dengan demikian, permasalahan yang ada di Desa Nglanggeran mulai dari alamnya yang kurang bersahabat, ditambah dengan perilaku warga yang memperburuk kondisi alam. Sehingga membuat kondisi masyarakat tambah parah dan banyaknya pemuda yang melakukan perantauan sebab di desanya tidak ada tempat untuk bekerja. Maka dari itu, dapat dikatakan Desa Nglanggeran menjadi desa yang alam dan penduduknya miskin, sepi, dan tertinggal.

Kedua, dengan didorong adanya masalah di atas, maka mereka melakukan usaha pemecahan masalah dengan berpijak pada potensi lokal yang mereka miliki. Berdasarkan teori pengembangan masyarakat lokal, tujuan intervensi sebenarnya untuk mengembangkan kapasitas masyarakat agar mampu memecahkan masalah ekonomi mereka sendiri dengan berbasis pada potensi lokal (baik sumber daya manusia dan alam), sehingga lahir kapasitas/kemampuan dalam memenuhi kebutuhan ekonomi mereka secara mandiri.

45 Ibid.

46 Ibid.

47 "Indonesia Membangun Harmoni Gunung Api Purba Nglanggeran," Video YouTube, 24:39, dikirim oleh
Dengan adanya permasalahan sosial ekonomi yang terjadi pada Nglanggeran tersebut, akhirnya pemuda desa bernama Sugeng Handoko tergerak untuk melakukan perubahan. la prihatin dengan keadaan masyarakat sekitarnya yang hidup dalam kondisi kekurangan, dan bertambah prihatin pula untuk memenuhi kebutuhan mereka sehari-hari, mereka menebangi pohon-pohonan, dan mengambil batu-batu yang tinggi menjulang tersebut untuk dijual.

Bersama-sama dengan kelompok-kelompok yang ada, antara lain pemuda Karang Taruna Putera Bukti Mandiri, mengajak para warga kampung, termasuk tokoh masyarakat mereka untuk membicarakan gagasan menjadikan Nglanggeran sebagai desa ekowisata dengan mengandalkan Gunung Api Batu Purba sebagai wahana wisata utamanya. ${ }^{47}$

Dari data yang diperoleh di atas, maka bisa dikatakan bahwa kegiatan intervensi mereka benar-benar dilalui melalui proses yang ulet, didialogkan dengan tokoh pemuda dan masyarakat. Walaupun ada tantangan-tantangan yang berdatangan, antara lain; a) para anggota Karang Taruna Putera Bukit Mandiri yang terlibat berguguran. Jumlahnya bahkan menyusut dari 40-an pemuda menjadi tinggal delapan orang; b) selain itu, meskipun kesadaran pemuda untuk menjaga lingkungan sebetulnya telah tumbuh sejak lama, mereka kerap diremehkan sebagai "bocah

“Gunung Api Purba Nglanggeran," April 26, 2016. https://www.YouTube.com/watch?v=YsdCn7MSEHw. 
kemarin sore," 48 namun mereka tetap konsisten dengan usaha memperjuangkan desa ekowisata mereka.

Dengan demikian maka tujuan intervensi yang ingin dicapai oleh para pemuda di atas tidak hanya berorientasi proses, melainkan juga hasil (process and output goal). Dalam mencari problem solving tersebut, Pokdarwis tetap berpijak pada potensi lokal yang ada, baik sumber daya manusia (seperti kepala desa, sesepuh kampung, dan lain-lain), sumber daya sosial berupa norma musyawarah, dan kegotongroyongan yang selama ini melekat dalam kehidupan seharihari masyarakat Nglanggeran.

Melibatkan aparat desa pun mau tidak mau harus dilakukan karena hampir $70 \%$ lahan Desa Nglanggeran yang akan menjadi destinasi wisata tersebut merupakan tanah milik pemerintahan desa, termasuk pula Gunung Api Purba yang menjadi destinasi utama wisata desa ini. Atas dasar itulah akhirnya Karang Taruna Bukit Putera Mandiri sebagai pihak pengelola wisata bersama-sama dengan pemerintah desa bekerja sama mengelola lahan seluas 48 hektar tersebut untuk dijadikan wahana wisata. kerja sama tersebut tertuang dalam SK Kepala Desa Nglanggeran No.05/KPTS/1999 tertanggal 12 Mei 1999. ${ }^{49}$

Dengan berpijak pada data di atas, maka tujuan intervensi komunitasnya ini tidak hanya berorientasi pada proses saja, yakni melibatkan partisipasi warga desa,

\footnotetext{
48 Elisabeth Adventa dan Markus Sumartomjon, "Kisah Sugeng Handoko mendirikan ekowisata Desa Nglanggeran (bagian 1)," Kontan.co.id, diakses pada tanggal 28 Mei 2020.

https://peluangusaha.kontan.co.id/news/kisah-sugenghandoko-mendirikan-ekowisata-desa-nglanggeranbagian-1.
}

melainkan juga berorientasi pada hasil. Meskipun proses yang dilalui melibatkan partisipasi penuh masyarakat, namun jika tidak menghasilkan pemecahan masalah, maka usaha melibatkan partisipasi masyarakat pun juga tidak ada artinya.

Ketiga, strategi dasar dalam melakukan intervensi tersebut mengandalkan segala sumber daya yang ada. Dari hasil data-data yang diperoleh, strategi pertama yang dilakukan oleh Sugeng Handoko adalah mengajak para tokoh pemuda, antara lain Ketua Karang Taruna Putera Bukit Mandiri, Mursidi, dan tokoh masyarakat setempat untuk membahas bersama-sama, bermusyawarah secara mufakat, diskusi dan interaksi dalam kelompok kecil tentang gagasan Desa Ekowisata Gunung Api Purba Nglanggeran. ${ }^{50}$ Dalam tayangan tersebut, salah satu tokoh desa menasihati bahwa setiap langkah apa pun harus dimusyawarahkan bersama dengan tokoh desa. Terdapat tokoh yang menyatakan dalam diskusi itu bahwa persatuan kesatuan dan kegotongroyongan tidak boleh ditinggalkan, pada prinsipnya jika memang kegiatan wisata tersebut ternyata dapat mengangkat ekonomi warga tentu akan didukung. ${ }^{51}$

Pijakan strategi ini pada dasarnya karena warga Desa Nglanggeran merupakan desa yang guyub, satu sama lain memiliki hubungan dan ikatan sosial yang erat. Dengan kata lain bahwa modal sosial berupa norma kegotongroyongan,

49 Fatchurrohman, "Institutional Entrepreneurship Pemuda dalam Mengembangkan Pokdarwis Desa Wisata Nglanggeran," 284.

50 "Indonesia Membangun Harmoni Gunung Api Purba Nglanggeran," Video YouTube, 24:39, dikirim oleh “Gunung Api Purba Nglanggeran,” April 26, 2016.

51 Ibid. 
persatuan/keguyuban menjadi kunci keberhasilan penggunaan strategi partisipasi. Sehingga dalam mengemukakan satu ide untuk kepentingan desa, norma tersebut tidak boleh diabaikan. Strategi melibatkan berbagai kelompok warga dalam menentukan dan memecahkan masalah mereka sendiri memang menjadi salah satu variabel dari pengembangan masyarakat lokal, namun sisi unik dari pelibatan/partisipasi masyarakat lokal Nglanggeran ini adalah adanya forum diskusi rutin yang dilakukan setiap 35 hari sekali, yang dikenal dengan forum Musyawarah Desa Seloso Kliwon. ${ }^{52}$

Hasil survei juga menunjukkan bahwa sebanyak $74,19 \%$ responden pernah dilibatkan dalam pengambilan keputusan terkait rencana pengembangan Desa Wisata Nglanggeran, setidaknya dalam bentuk kegiatan musyawarah. ${ }^{53}$ Di lain sisi kepariwisataan di Desa Wisata Nglanggeran sendiri merupakan kegiatan padat karya, oleh karena itu kegiatan desa wisata membutuhkan keterlibatan penuh dari berbagai elemen masyarakat, terlebih-lebih saat ada kunjungan wisatawan cukup ramai, Pokdarwis Nglanggeran sebagai pengelola pun melibatkan kelompok-kelompok masyarakat yang lebih besar seperti kelompok tani, kelompok kesenian, kelompok usaha kerajinan dan kuliner, dan lain-lain. ${ }^{54}$

Selain mengajak kerja sama internal warga mereka sendiri, Pokdarwis juga membuka

52 "Inovasi Desa Wisata Nglanggeran : Mengamankan Pendapatan Desa Wisata melalui Penerapan ETICKETING," video YouTube, 7:24, dikirim oleh "Gunung Api Purba Nglanggeran," December 27, 2017. https://www.youtube.com/watch?v=ISyOPJszhJ0

53 Hary Hermawan, "Dampak Pengembangan Desa Wisata Nglanggeran Terhadap Ekonomi Masyarakat Lokal," Jurnal Pariwisata, vol. 3, no. 2 (2016): 105 diri melibatkan pihak eksternal mereka untuk bekerja sama. Hal ini bisa dilihat pihak-pihak eksternal yang terlibat dalam usaha intervensi komunitas Desa Nglanggeran ini. Mereka antara lain: pihak pemerintah daerah propinsi lewat penerimaan dana hibah dari Gubernur Jawa Tengah, Ganjar Pranowo yang kemudian dialokasikan dana tersebut untuk pembuatan embung (bendungan buatan). ${ }^{55}$ Pembuatan embung ini bertujuan untuk mengatasi masalah kekeringan saat musim kemarau, sehingga para petani masih bisa merawat tanaman padi dan kebun buahnya meski musim kekeringan melanda. Dan ternyata keberadaan embung, tidak hanya berfungsi untuk pengairan, tetapi juga dimanfaatkan airnya untuk peternakan ikan. Embung dengan kapasitas $12.000 \mathrm{~m}^{3}$ dapat menampung ikan sampai ribuan. Dengan memelihara ikan tersebut, dapat memberikan pemasukan masyarakat desa. Bahkan, dengan adanya pembuatan embung ini, dapat memberikan kawasan wisata baru. Embung dapat menjadi kawasan wisata karena pemandangannya yang bagus, terlihat hijau, dan saat sunset/sunrise, pemandangan menjadi indah. Dengan adanya peternakan ikan dan menjadikan kawasan ekowisata ini membuat pendapatan mengalami peningkatan dan Embung pun menjadi kawasan wisata yang foto-fotonya telah beredar di media sosial. ${ }^{56}$

Selain pihak pemerintah, Pokdarwis juga bekerja sama dari pihak swasta, yaitu Bank

\footnotetext{
${ }^{54}$ Ibid.

55 Fatchurrohman, "Institutional Entrepreneurship Pemuda dalam Mengembangkan Pokdarwis Desa Wisata Nglanggeran," 284.

56 "Wisata Edukasi: Waduk Nglanggeran Jogja-Obor Tani," Video YouTube, 04:57, dikirim oleh "Film Obor Tani-Ilmu Tani-Agus Merdeka," November 8, 2017. https://youtu.be//Hy35nqznqc.
} 
Mandiri, Bank BRI, P.T. Pertamina, dan BPD. kerja sama mereka dalam bentuk penerimaan bantuan operasional pelatihan dari swasta tersebut, perbaikan infrastruktur, dan memperbaiki fasilitas yang kurang. Selain mendapatkan bantuan dana untuk keperluan tersebut, juga diberikan pelatihan, workshop, dan diskusi untuk mengembangkan ide kreatif masyarakat. ${ }^{57}$ Termasuk pula bekerja sama dengan pihak keraton Yogyakarta. Untuk meningkatkan minat wisata, Pokdarwis pun menambahkan sekali lagi destinasi wisata berupa perawatan spa. Pada pengadaan spa, Pokdarwis bekerja sama dengan Tim Putri Kedaton pimpinan Lastiyani Wari Wulandari untuk melatih massage pada 20 orang perempuan Desa Nglanggeran. Pelatihan yang diberikan kepada masyarakat Desa Nglanggeran akan diberikan sertifikasi jika lulus dalam persyaratan teknis yang dibukukan oleh ahli. ${ }^{58}$ Pengadaan spa menggunakan bahan-bahan produk lokal seperti, susu kambing etawa, cokelat, kenanga, dan selainnya. ${ }^{59}$ Demikian juga bekerja sama dengan lembaga pendidikan dan penelitian, antara lain UGM, LIPI, UPN Yogyakarta, dan lain-lain. Dengan bantuan tersebut diharapkan masyarakat dalam pengelolaan dapat berjalan secara kontinu. ${ }^{60}$

Keempat, karakteristik taktik dan teknik perubahan, sebagaimana yang disebutkan dalam kerangka teori, karakteristik taktik dan teknik perubahan yang dimaksud

\footnotetext{
57 Fatchurrohman, "Institutional Entrepreneurship Pemuda dalam Mengembangkan," 290-291.

58 Tomi Sudjatmiko, "Siapkan Wisata Spa, Terapis Desa Wisata Nglanggeran Mendapat Pelatihan," krjogja.com, diakses $\quad 25 \quad$ Agustus 2019 https://krjogja.com/web/news/read/40829/Siapkan Spa Terapis Desa Wisata Nglanggeran Mendapat Pelatiha $\underline{\text { n. }}$
}

adalah cara-cara teknis/spesifik dari alternatif strategi yang dipilih. Adapun taktik dan teknik perubahan yang dipilih adalah komunikasi kelompok berupa diskusi atau musyawarah baik dengan tokoh masyarakat dan pemuda yang tergabung dalam Karang Taruna Putera Bukit Mandiri. Strategi tersebut juga disampaikan pada awal kali mereka mengajukan ide Desa Ekowisata Gunung Api Purba maupun pengembangan ide-ide destinasi wisata selain Gunung Api Purba lainnya, seperti: Embung Nglanggeran, Air Terjun Musiman "Kedung Kandang", wisata edukasi "membuat makanan olahan berbahan dasar cokelat", wisata edukasi peternakan kambing etawa, dan lain-lain. Demikian juga saat mereka menemukan masalah bagaimana mengetahui dengan mudah, murah, dan cepat jumlah pengunjung dan pendapatan harian, sehingga dapat menghindari kebocoran pendapatan asli desa, maka Pokdarwis Nglanggeran berinisiatif menyelenggarakan tiket masuk secara digital. Ide ini direalisasikan melewati proses yang panjang, yakni diskusi internal pengurus Pokdarwis, setelah disepakati bersama oleh para anggota pengurus, maka mereka mengemukakan ke forum warga masyarakat secara umum

\footnotetext{
59 "Pengembangan Wisata EcoSPA di Nglanggeran Gunung KIdul, Yogyakarta," Video YouTube, 12:06, dikirim oleh "Lastiani Wulan," 23 September 2017 https://youtu.be/95yyMh3BKJ4.

60 "Pengembangan Agrowisata Gunungkidul, Gubernur Resmikan 'Griya Cokelat'," KabarHandayani, diakses 24 Agustus 2019 . http://kabarhandayani.com/pengembangan-agrowisatagunungkidul-gubernur-resmikan-griya-cokelat/.
} 
dalam forum Musyawarah Desa Seloso Kliwon. ${ }^{61}$

Dalam forum tersebut, warga senantiasa terlibat bersama-sama mendiskusikan setiap aspirasi yang masuk, dan mereka bersama-sama menyepakati setiap keputusan yang diambil. Bahkan forum tersebut juga digunakan sebagai media bagi warga untuk mengangsur dana pinjaman yang diperoleh dari Koperasi Nglanggeran yang diperuntukkan membiayai pembangunan homestay mereka. ${ }^{62}$ Pokdarwis melakukan taktik dan teknik ini dikarenakan mereka memahami nilai dan norma sosial yang ada, termasuk pula modal sosial yang lain, yang dikenal dengan bonding social capital, yaitu kepercayaan terhadap warga satu dengan lainnya yang mewujud dalam bentuk kebiasaan gotong royong/kerja bakti. Gotong royong atau kerja bakti ini diperlihatkan oleh mereka saat mempersiapkan potensi Gunung Api Purba mereka dengan membersihkan kawasan tersebut dari sampah, membangun jalur pendakian, membangun posko-posko tempat peristirahatan, membangun jalan, penerangan, dan lainlain. Modal sosial demikian yang membuahkan mereka mudah sekali memufakati setiap keputusan yang diambil.

Kelima, dalam rangka mengintervensi warga Nglanggeran, pihak pemegang otoritas (kepala desa, ketua RW, RT, dan lain-lain) menjadi pihak yang akan

61 “Inovasi Desa Wisata Nglanggeran: Mengamankan Pendapatan Desa Wisata melalui Penerapan ETICKETING," video YouTube, 7:24, dikirim oleh "Gunung Api Purba Nglanggeran," December 27, 2017.

https://www.youtube.com/watch?v=ISyOPJszhJ0

62 Dinar Wahyuni, "Strategi Pemberdayaan Masyarakat Dalam Pengembangan Desa Wisata Nglanggeran," diorientasikan sebagai partner/kolaborator. Pada video yang ditayangkan oleh TVRI Yogya, disebutkan bahwa dalam musyawarah desa mereka melibatkan bersama-sama pihak tokoh desa, baik yang berasal dari unsur kepala desa, kepala dusun, RT, RW, ketua karang taruna, dan seterusnya. ${ }^{63}$

Di situ disebutkan bahwa pihak berwenang (kepala desa, kepala dusun, dan lain-lain) ternyata diposisikan sebagai partner/kolaborator yang bekerja bersamasama memecahkan masalah yang dihadapi oleh komunitas lokal tersebut. Bahkan Kepala Desa yang bernama Bapak Sediyono, menyampaikan ucapan simpatinya atas peran serta pemuda yang telah berinisiatif menjadikan Gunung Api Purba yang semula tidak memiliki nilai ekonomis sama sekali menjadi nilai ekonomi tinggi, ${ }^{64}$ dan sebagai akibat dari itu, maka yang terangkat tidak hanya potensi alam Gunung Api Purba tetapi juga potensi budaya seperti kirab budaya, jathilan, jaranan, dan lain-lain menjadi terangkat.

Kolaborasi tersebut tidak hanya dibuktikan lewat keterlibatan para tokoh dan pihak berwenang masyarakat dalam tiap musyawarah desa, tetapi juga dibuktikan lewat SK 8 Mei 1999 yang berisi keputusan untuk menyerahkan tanah desa seluas 48 ha untuk dikelola oleh kelompok sadar

Aspirasi: Jurnal Masalah-Masalah Sosial, vol. 9, no.1 (2018): 91.

63 "Indonesia Membangun Harmoni Gunung Api Purba Nglanggeran," Video YouTube, 24:39, dikirim oleh "Gunung Api Purba Nglanggeran," April 26, 2016. https://www.YouTube.com/watch?v=YsdCn7MSEHw.

64 "Video Pemuda Pelopor Sugeng Handoko," video YouTube, 9:22, dikirim oleh "Sugeng Handoko," October 16, 2011. https://youtu.be/jOVwHkESbpY. 
wisata (Pokdarwis) Nglanggeran. Dengan penyerahan pengelolaan kawasan Gunung Api Purba kepada karang taruna. Mereka melakukan reboisasi penanaman buahbuahan yang produktif sebagaimana yang telah disinggung di atas. Sehingga di kawasan Gunung Api purba juga mengalami penghijauan kembali dan menghasilkan buah-buahan yang produktif.

Melalui kegiatan pariwisata berbasis lingkungan inilah, kemudian berkembang berbagai macam usaha penduduk desa, antara lain: disediakannya homestay, agar tamu wisata yang menginap mendapatkan kemudahan untuk bermalam, dengan demikian memberikan keuntungan tersendiri pula baik bagi Pokdarwis selaku pengelola wisata, maupun penduduk sebagai pengelola homestay. Efek lebih lanjut masyarakat Nglanggeran dulu tidak banyak yang memiliki kamar mandi yang higienis. Dengan adanya program Live In as local people yang menjadi salah satu paket ekowisata Gunung Api Purba Nglanggeran, membuat warga Nglanggeran akhirnya beramai-ramai membangun kamar mandinya secara higienis. ${ }^{65}$

Keenam, pengembangan masyarakat lokal menggunakan kelompok-kelompok diskusi sebagai media untuk memaparkan gagasan, mengajak bersama merumuskan masalah, pemecahan masalah/kebijakan, membangun kesepakatan, dan lain-lain. Di Nglanggeran, kelompok-kelompok diskusi tersebut diadakan oleh Pokdarwis (Kelompok Sadar Wisata) Nglanggeran yang

65 "Sugeng Handoko Pemberdayaan Pemuda dan Masyarakat Gunung Api Purba," Video YouTube, 18:26, dikirim oleh "Sugeng Handoko," November 10, 2014. https://youtu.be/YcPteZLHa1l..

66 "Inovasi Desa Wisata Nglanggeran : Mengamankan Pendapatan Desa Wisata melalui Penerapan E- diikuti oleh perwakilan dusun dan desa, termasuk tokoh-tokoh masyarakat lainnya. Misalkan saat merumuskan ide e-ticketing untuk mendapatkan informasi secara cepat jumlah wisatawan dan pendapatan yang masuk pada hari tersebut, sebelum disampaikan dalam forum musyawarah warga desa, mereka terlebih dulu berdiskusi antar sesama pengurus Pokdarwis. Setelah dianggap matang, maka mereka pun memflooring-kan gagasan tersebut ke forum Selasa Kliwon, dan dari forum tersebut, warga desa menyetujui untuk direalisasikan. ${ }^{66}$

Ketujuh, sebagaimana yang dilakukan oleh Sugeng Handoko dan kawan-kawannya selama ini, menunjukkan peran sebagai seorang pemungkin (enabler), yaitu pihak yang mampu menjadikan/memungkinkan desa yang semula dikenal dengan desa gersang, miskin, sepi, menjelma menjadi desa yang hijau, bergerak secara bertahap dari keadaan yang serba kekurangan kemudian membaik, dan ramai sekali oleh pengunjung/wisatawan. Hal-hal yang membuat para praktisi wisata ini sukses merealisasikan desa mereka menjadi desa ekowisata adalah kerja keras mereka dalam mempersuasi para penduduk desa agar tidak lagi mengeksploitasi kayu dan batu yang berada di sekitar area Gunung Api Nglanggeran. Tidak hanya itu, mereka juga memanfaatkan linking social capital, yaitu memanfaatkan link/jaringan dengan pemerintahan tingkat atas desa, yaitu pemerintahan kecamatan Patuk,

TICKETING," video YouTube, 7:24, dikirim oleh "Gunung Api Purba Nglanggeran," December 27, 2017. https://www.youtube.com/watch?v=ISyOPJszhJ0. 
pemerintahan kabupaten Gunung Kidul dan Pemerintahan Provinsi Jawa Tengah.

Termasuk pula menggandeng lembaga penelitian, yaitu LIPI Yogyakarta agar membantu mereka membuatkan teknologi sederhana pengolahan produk olahan cokelat, menggandeng pula pihak UGM sebagai stakeholder yang menyediakan tenaga ahli pendampingan bagi petani mina padi, petani buah-buahan, peternak kambing etawa, dan lain-lain. Termasuk pula menggandeng pihak Universitas Pembangunan Nasional (UPN) Yogyakarta yang berjasa membangun sumur-sumur injeksi di beberapa titik, sebagai usaha untuk mengurangi kekeringan yang secara alamiah terjadi di sekitar Nglanggeran. Adapun kekeringan ini terjadi disebabkan oleh posisi/letak geografis Nglanggeran berada di titik cekungan ekstrem, sehingga air yang terserap di tanah desa tersebut tidak mampu ditangkap dalam kurun waktu lama.

Dengan adanya usaha Pokdarwis dalam mengembangkan kawasan wisata dan memberdayakan masyarakat, tidak luput dari adanya tindakan melakukan analisis masalah yang terjadi di Desa Nglanggeran dan strategi yang digunakan untuk mengatasi masalah agar mencapai sebuah tujuan. Dengan demikian, dapat dikatakan bahwa Pokdarwis juga melakukan peran analisis sebuah masalah dan pemecahan masalah serta fasilitator untuk membuat masyarakat Desa Nglanggeran memiliki

67 "Indonesia Membangun Harmoni Gunung Api Purba Nglanggeran," Video YouTube, 24:39, dipublikasikan oleh Gunung Api Purba Nglanggeran. Istilah "selapan" atau "selapanan" berasal dari Bahasa Jawa yang berarti 35 hari. 68 Hermawan, "Dampak Pengembangan Desa Wisata Nglanggeran Terhadap Ekonomi Masyarakat Lokal," 110. kemampuan atau keterampilan. Sehingga masyarakat dapat memenuhi kebutuhannya secara mandiri. Mendapat keterampilan ini dari bantuan stakeholders yang memberikan bantuan dana dan pelatihan.

Pokdarwis juga melakukan tindakan evaluasi dan perencanaan yang dilakukan 35 hari sekali atau pada waktu selapan. ${ }^{67}$ Lembaga ini juga melakukan pengelolaan kawasan wisata. Pengelolaan kawasan tersebut dikelola sebanyak 169 orang. Sebanyak 50 orang adalah anggota/pengurus inti dan 119 adalah anggota. Ketika ada paket kunjungan wisatawan dalam skala besar, Pokdarwis menggandeng kelompok-kelompok di masyarakat, seperti kelompok tani, kelompok kesenian, kelompok kerajinan, dan kuliner dan lain-lain. ${ }^{68}$ Dengan adanya penggabungan kelompok-kelompok, maka diperlukannya sebuah akomodasi kepentingan bersama supaya berjalan dengan lancar. Akan tetapi, pernah terjadinya perbedaan persepsi di masyarakat. Kejadian tersebut dapat dikendalikan oleh Pokdarwis dengan melakukan musyawarah ataupun saling interaksi. Maka dari itu, Pokdarwis juga melakukan pengelolaan konflik yang terjadi pada kegiatan wisata. ${ }^{69}$

Pokdarwis menginisiasi pengadaan $e$ ticketing dengan tujuan memecahkan persoalan kebutuhan administrasi yang lebih rapi, efisien/cepat, dan transparan. ${ }^{70}$

69 Fatchurrohman, "Institutional Entrepreneurship Pemuda dalam Mengembangkan Pokdarwis Desa Wisata Nglanggeran," 286.

70 "Inovasi Desa Wisata Nglanggeran: Mengamankan Pendapatan Desa Wisata melalui Penerapan ETICKETING," Video YouTube, 07:24, dikirim oleh "Gunung Api Purba Nglanggeran," December 27, 2017, https://youtu.be/ISyOPJszhJ0. 
Dengan demikian, tindakan yang dilakukan Pokdarwis adalah perencana dan pelaksana program. Demikian juga saat mengadakan kerja sama dengan berbagai pihak agar bisa mempotensikan segala sumber daya yang ada sehingga mampu meningkatkan kapasitas kemandirian ekonomi masyarakat, maka peran yang telah dilakukan oleh Pokdarwis adalah fasilitator.

Kedelapan, batasan penerima layanan (wilayah/masalah) terbatas pada wilayah lokal tertentu, yaitu seluruh Desa Nglanggeran. Memang dari sisi ini, tidak seluruh dusun yang masuk Desa Nglanggeran menikmati keberkahan dari kesuksesan desa ekowisata ini, karena letak Gunung Api itu sendiri berada di wilayah dusun Nglanggeran Wetan, dusun Nglanggeran Kulon, dan dusun Gunung Butak. Namun dusun lain yang jauh dari Gunung Api Purba, seperti dusun Dago dan Karangsari, relatif belum merasakan perubahan tersebut. Namun pihak Pokdarwis sekarang dalam tahap mencarikan format partisipasi yang baik, agar seluruh warga dusun di Nglanggeran menikmati keberhasilan desa ekowisata mereka.

Kesembilan, kepentingan kelompokkelompok dalam suatu komunitas. Kepentingan kelompok-kelompok di Desa Nglanggeran saling bersatu padu mendukung Desa Ekowisata Gunung Api Nglanggeran. Warga Desa Nglanggeran bisa dikatakan memiliki bonding social capital yang sangat kuat. Hal ini bisa diketahui bahwa dari segi latar belakang suku bangsa/budaya, $99 \%$ adalah suku asli Jawa, agama 98\% Islam, dan kebiasaan diskusi tiap Selasa kliwon (35 hari sekali) yang mengundang seluruh elemen masyarakat menunjukkan bahwa mereka memiliki satu kesatuan tujuan bersama, yaitu membangun kesejahteraan masyarakat desa.

Kesepuluh, konsepsi penerima layanan. Melalui hasil penggalian data, maka penerima layanan pemberdayaan masyarakat Nglanggeran adalah seluruh elemen masyarakat Desa Nglanggeran, antara lain: terutama para pemuda yang tergabung dalam Karang Taruna Putera Bukit Mandiri yang seluruhnya merupakan anggota dan pengurus Pokdarwis, peternak kambing etawa (ada sekitar 60 anggota), petani cokelat, ibu-ibu PKK sebagai SDM utama pembuat cokelat olahan (ada sekitar 25 anggota), keluarga/rumah tangga pengelola homestay ada sekitar $80 \mathrm{KK}$, pedagang asongan, seperti kaos, nasi bungkus, warung kopi, petani mina padi, dan seluruh anggota masyarakat Nglanggeran lainnya.

Kesebelas, konsepsi mengenai kelompok penerima manfaat dan peran sertanya dari usaha pengembangan masyarakat lokal ini adalah warga Nglanggeran itu sendiri. Mereka terdiri dari individu dan kelompok. Kelompok penerima layanan tersebut terdiri dari keluarga/rumah tangga, kelompok petani, baik petani padi maupun petani perkebunan (buah-buahan), ibu-ibu PKK, kelompok peternak kambing, dan sebagainya. Para penerima manfaat ini memiliki peran yang sama pentingnya dengan subjek pemberdaya yaitu Pokdarwis itu sendiri. Mereka menjadi bagian dari subjek kegiatan pembangunan/pemberdayaan yang mereka lakukan. Contoh yang bisa disampaikan sebagai berikut: pada pembangunan pengelolaan kakao, dilakukan dengan mengajak masyarakat 
petani dan ibu-ibu PKK untuk melakukan membuat makanan olahan cokelat. Bekerja sama dengan para petani cokelat dan peternak kambing etawa, maka kelompok ibu-ibu PKK sebagai segmen pembuat makanan olahan cokelat mendapatkan suplai bahan baku dari produk ini. Oleh karena ada kendala belum memiliki teknologi olahan cokelat dalam skala kecil dan sederhana, maka Pokdarwis menggandeng LIPI Yogyakarta untuk bekerja sama. LIPI sebagai pihak penemu dan pelatih teknologi pembuatan cokelat skala kecil dan sederhana. ${ }^{71}$ Masyarakat yang terlibat dalam pengelolaan kakao sebanyak 5 kelompok tani dengan jumlah 645 orang dan 25 Ibu-lbu PKK. ${ }^{72}$ Dengan terkumpulnya masyarakat tersebut, maka dibentuknya pengelolaan tersebut dengan nama 'Gapoktan Kumpul Makaryo'. Gapoktan mempromosikan dengan kalimat 'Mempunyai Unggulan Olahan Cokelat Purba Rasa'. ${ }^{73}$

Dengan adanya pengelolaan kakao tersebut, maka kebutuhan kakao menjadi lebih banyak. Bahkan, dalam pembuatan minuman ataupun dodol juga menggunakan bahan tambahan susu dari kambing etawa. Dengan adanya hal itu, maka perlu adanya tambahan penanaman pohon dan kambing etawa. Kebutuhan tersebut dapat tercapai dengan pemberian

71 "Kisah Sukses Griya Cokelat Nglanggeran Gunungkidul," Video YouTube, 02:24, dikirim oleh "Gunung Api Purba Nglanggeran," Agustus 31, 2017. https://youtu.be/4 HI87BlvDQ.

72 "BNI Taplus Bisnis Video Competition with Kumparan Griya Cokelat Nglanggeran," Video YouTube, 03:00, dikirim oleh "Ifin Primandiri," April 6, 2018. https://youtu.be/dSL7sXoMKzw

73 "Company Profile Griya Cokelat Nglanggeran," Video YouTube, 04:00, dikirim oleh "Gunung Api Purba Nglanggeran," $\quad$ Agustus 20, 2017. https://youtu.be/890gz3XIct4

${ }^{74}$ Admin1 (LD), "LIPI-BI Mengembangkan Pembudidayaan Kakao di Gunung Kidul," Balai Penelitian Teknologi Bahan bantuan dari pemerintah D.I. Yogyakarta memberikan bantuan berupa penanaman bibit kakao sebanyak 1.000 buah ${ }^{74}$ dan bantuan dari BPTP (Balai Pengkajian Teknologi Pertanian) Jawa Tengah berupa kambing dan kandang. ${ }^{75}$

Dengan pengelolaan diserahkan oleh IbuIbu PKK dan kelompok tani serta ternak, khususnya dalam pengelolaan produk jika ada kendala akan dibantu oleh LIPI. LIPI bersiap memberikan bantuan berupa menampung dan menyelesaikan permasalahan penerapan teknologi di masyarakat dan memberikan pembinaan kepada SDM yang siap menampung ilmu teknologi. Dengan bantuan tersebut diharapkan masyarakat dalam pengelolaan dapat berjalan secara kontinu. ${ }^{76}$ Produk tersebut hingga kini kemudian berkembang juga mengelola kripik pisang.

Sehingga dari pemaparan di atas, bisa dikatakan bahwa konsepsi penerima layanan diasumsikan sebagai pihak yang aktif, punya sumber dayanya masingmasing, sehingga mereka dianggap mampu untuk terlibat bersama dalam usaha meningkatkan kapasitas kemandirian ekonomi mereka. Para warga Desa Nglanggeran yang terdiri dari berbagai segmen ini, agar keseluruhannya bisa menemukan titik kepentingan dan kebutuhan yang sama, mereka dimediasi

\footnotetext{
Alam-LIPI, diakses 24 Agustus 2019, http://bptba.lipi.go.id/bptba3.1/?lang=id\&u=blogsingle\&p=494.

75 "TTP Nglanggeran, Gunung Kidul, Yogyakarta, Jawa Tengah," video YouTube, 03:51, dikirim oleh "Likco Balingtan," October 19, 2016. https://youtu.be/Setf40 10is.

76 "Pengembangan Agrowisata Gunungkidul, Gubernur Resmikan 'Griya Cokelat',' KabarHandayani, diakses 24 Agustus 2019, http://kabarhandayani.com/pengembangan-agrowisatagunungkidul-gubernur-resmikan-griya-cokelat/.
} 
dalam sebuah forum diskusi yang diadakan 35 hari sekali tiap hari Selasa Kliwon. Forum tersebut tidak hanya bertujuan menampung aspirasi dari para penduduk terkait pengembangan desa wisata mereka, tetapi juga berisi evaluasi atas pelaksanaan desa wisata selama ini, sekaligus pembahasan ide-ide baru sebagai solusi atas masalah yang mereka temukan. ${ }^{77}$ Berdasarkan hasil penelitian Hermawan, proses pengambilan keputusan pada kelompok diskusi ini, hampir $74,19 \%$ dari responden yang ditetapkan turut andil dalam proses pengambilan keputusan. ${ }^{78}$ Dengan demikian, masyarakat Desa Nglanggeran dalam pengambilan keputusan bisa dikatakan memiliki nilai partisipasi yang tinggi.

Keduabelas, dengan demikian maka pemanfaatan intervensi komunitas, dari hasil pemaparan hal-hal di atas, ternyata mampu mengembangkan kapasitas komunitas warga Desa Nglanggeran. Hal ini tidak hanya mampu meningkatkan kapasitas perekonomian mereka, tetapi juga mampu meningkatkan kemandirian warga desa ini dalam mengambil keputusan bersama untuk mencari hal yang terbaik buat pengembangan desa wisata mereka. Peningkatan kapasitas ini dengan sendirinya mampu membangkitkan rasa percaya diri masing-masing orang.

\section{Kesimpulan}

Melalui pembahasan di atas, dapat diketahui bahwa model pengembangan masyarakat lokal memiliki karakteristik khas

77 "Indonesia Membangun Harmoni Gunung Api Purba Nglanggeran," Video YouTube, 24:39, dikirim oleh "Gunung Api Purba Nglanggeran," April 26, 2016. https://www.YouTube.com/watch?v=YsdCn7MSEHw. sebagai berikut: pertama, masalah yang mereka hadapi adalah kemiskinan, bencana alam berupa kekeringan hebat saat musim kemarau, rendahnya tingkat pendidikan, minimnya akses desa ke pusat kota ( $25 \mathrm{~km})$, sehingga bisa dikatakan desa ini rawan bencana kelaparan. Sedangkan di sisi lain, desa ini memiliki potensi sumber daya alam dan sosial yang bisa dimanfaatkan untuk mengatasi kerawanan bencana alam tersebut. Potensi tersebut, antara lain ciri homogenitas sosial masyarakat Nglanggeran yang sebagian besar adalah orang Jawa, beradat Jawa, Islam, dan bermata pencaharian sebagai petani. Dengan kehomogenitasan ciri sosial ini, warga Nglanggeran memiliki kekayaan modal sosial berupa nilai-nilai kebersamaan, kegotongroyongan, musyawarah mufakat, dan lain-lain yang dapat dimanfaatkan untuk kepentingan pembangunan desa tersebut.

Mengingat karakteristik desa demikian, maka strategi yang digunakan oleh Pokdarwis sebagai subjek pengembang masyarakat lokal dalam memutuskan segala sesuatunya mengajak diskusi/musyawarah bersama lewat forum selapanan. Lewat forum tersebut, mereka menemukan berbagai ide problem solving, menemukan titik perbedaan sehingga melahirkan kekompakkan dalam merealisasikannya. Strategi di atas dikombinasikan dengan strategi lainnya yaitu memanfaatkan berbagai potensi lokal masyarakat untuk kepentingan kepariwisataan secara terintegrasi. Baik dimanfaatkan sebagai wahana wisata, oleh-oleh wisata, penginapan wisata, maupun pemenuhan

78 Hermawan, "Dampak Pengembangan Desa Wisata Nglanggeran Terhadap Ekonomi Masyarakat Lokal," 110 
kebutuhan ekonomi masyarakat secara langsung. Dan menariknya pengintegrasian potensi alam tersebut disokong oleh pihak eksternal, seperti UGM, Yayasan Obor Tani, dan lain-lain.

Dengan demikian bisa dikatakan bahwa keberhasilan mereka keluar dari kemiskinan karena disebabkan berbagai hal, mulai dari strategi perubahan mereka yang sesuai/kompatibel dengan karakteristik unik sosial mereka yang homogen, aktif partisipatif, terlebih-lebih ada forum 35 harian yang menjadi penggerak lahirnya inovasi-inovasi lanjutan, serta kiprah/sepak terjang Pokdarwis sebagai motor penggerak kepariwisataan desa tersebut.

Melalui studi di atas, bisa direkomendasikan bahwa melalui kajian keunikan pengembangan masyarakat lokal sektor ekonomi pada Desa Nglanggeran dapat dipahami bahwa usaha pengembangan masyarakat lokal pada tiap desa memiliki kekhasan/perbedaan antara desa satu dengan desa lainnya, sehingga strategi perubahan yang berhasil digunakan pada desa tersebut belum tentu bisa diterapkan pada desa lain. Meskipun demikian terdapat beberapa strategi pengembangan masyarakat lokal yang bernilai prinsipil tetap berlaku bagi komunitas yang lain juga. Melalui kajian di atas, bagi pelaku/aktivis pengembangan masyarakat Islam bisa mengkaji faktor-faktor penyebab keberhasilan pengembangan masyarakat lokal pada Desa Nglanggeran ini, sehingga dapat diperoleh berbagai ragam referensi yang dapat memperkaya wawasan/pengetahuan tentang usaha perubahan masyarakat menuju ke arah yang lebih baik, yaitu masyarakat yang makmur dan sejahtera.

\section{Bibliografi}

Adi, Isbandi Rukminto. Ilmu Kesejahteraan Sosial dan Pekerjaan Sosial: Pengantar pada Pengertian dan Beberapa Pokok Bahasan. Depok: FISIP UI PRESS, 2005. . Intervensi Komunitas dan Pengembangan Masyarakat sebagai Upaya Pemberdayaan Masyarakat. Edisi Revisi 2012. Jakarta: RajaGrafindo Persada, 2012.

Admin1 (LD). "LIPI-BI Mengembangkan Pembudidayaan Kakao di Gunung Kidul." Balai Penelitian Teknologi Bahan Alam-LIPI. August 24, 2019. http://bptba.lipi.go.id/bptba3.1/?lang=id\&u=blog-single\&p=494. Adventa, Elisabeth dan Markus Sumartomjon. "Kisah Sugeng Handoko mendirikan ekowisata Desa

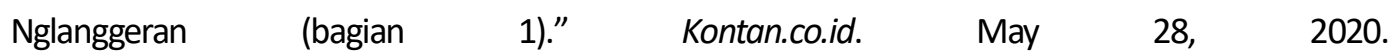
https://peluangusaha.kontan.co.id/news/kisah-sugeng-handoko-mendirikan-ekowisata-desanglanggeran-bagian-1

Ahmad, Amrullah. "Strategi Dakwah Islam di Tengah Era Reformsi menuju Indonesia Baru dalam Memasuki Abad ke-21," Makalah, Sarasehan Nasional: "Menggagas Dakwah Menuju Indonesia Baru," SMF Dakwah IAIN Sunan Gunung Djati, Bandung, 21 April 1999.

Aliyudin, Mukhlis. "Pengembangan Masyarakat Islam Dalam Sistem Dakwah Islamiyah" Jurnal Ilmu Dakwah vol. 4, no. 14 (2009): 777-792. https://journal.uinsgd.ac.id/index.php/idajhs/article/view/421. 
Al-Qurân al-Karîm Departemen Agama Rl. al-Qur'an dan Terjemahannya. Jakarta: P.T. Kumudasmoro Grafindo Semarang, 1994.

Asmin, Ferdinal. "Analisis Resiko Implementasi Kegiatan Pengembangan Masyarakat Sekitar Hutan di Sumetera Barat." Jurnal Sistemasi: Sistem Informasi vol. 8, no. 1 (2019): 194-203. DOI: 10.32520/stmsi.v8i1.396.

Aziz, M. Ali. Ilmu Dakwah. Jakarta: Kencana, 2009.

Berita Resmi Statistik. "Persentase Penduduk Miskin Maret 2019 Sebesar 9,41 Persen." Badan Pusat Statistik. August 3, 2019, https://www.bps.go.id/pressrelease/2019/07/15/1629/persentase-pendudukmiskin-maret-2019-sebesar-9-41-persen.html.

Dharmawan, Liliek. "Berhenti Jadi penebang Menjadi Penyelamat Lingkungan." Media Indonesia. October 2016. https://mediaindonesia.com/read/detail/74124-berhenti-jadi-penebang-menjadipenyelamat-lingkungan.html.

Faoziyah, Siti. "Intervensi Pengembangan Masyarakat Melalui Model Pengelolaan Pesisir Karangsong Kabupaten Indramayu." ICSW: International Conference on Social Work, (2020): 1-21. https://jurnal.umj.ac.id/index.php/ICSW2019/article/view/6878.

Fatchurrohman, Luthfi Nurwafi. "Institutional Entrepreneurship Pemuda dalam Mengembangkan Pokdarwis Desa Wisata Nglanggeran." Jurnal Studi Pemuda vol. 4, no. 2 (2015): 281-295. DOI: 10.22146/studipemudaugm.36813.

Firmansah. "Desa Wisata Nglanggeran sebagai Destinasi Wisata Berbasis Ekowisata di Yogyakarta," Domestic Case Study, Sekolah Tinggi Pariwisata Ambarukmo Yogyakarta, 2.

Hajar, Ibnu. "Dakwah Bil-Hal Dalam Perspektif Al-Qur'an (Studi Terhadap Ayat-Ayat Dakwah Bil-Hal Dalam Tafsir Ibnu Katsir)." Skripsi, Universitas Muhammadiyah Metro, 2015.

Hermawan, Hary. "Dampak Pengembangan Desa Wisata Nglanggeran Terhadap Ekonomi Masyarakat Lokal." Jurnal Pariwisata vo. 3, no. 2 (2016): 105-117. DOI: 10.31311/par.v3i2.1383.

Iswinarno, Chandra dan Muhammad Ilham Baktora. "Kemarau Panjang, 15 Kecamatan di Gunungkidul Terdampak Kekeringan.” suarajogja.id. 2019. https://jogja.suara.com/read/2019/11/05/160610/kemarau-panjang-15-kecamatan-digunungkidul-terdampak-kekeringan?page=1.

Jamalina, Ismi Atikah dan Dyah Titis Kusuma Wardani. "Strategi Pengembangan Ekowisata Melalui Konsep Community Based Tourism (CBT) dan Manfaat Sosial dan Ekonomi Bagi Masyarakat di Desa Wisata Nglanggeran, Patuk, Gunung Kidul." Jurnal Ekonomi dan Studi Pembangunan vol. 18, no. 1 (2017): 71-85. DOI: 10.18196/jesp.18.1.4008.

Kriyantono, Rachmat. Teknik Praktis Riset Komunikasi: Disertai Contoh Praktis Riset Media, Public Relation, Advertising, Komunikasi Organisasi, Komunikasi Pemasaran. Jakarta: Kencana Prenada, 2010.

Kusumaningtyas, Shela. "Kiprah Sugeng Handoko, Penggerak di Balik Ekowisata Desa Nglanggeran." Kompas.com. January 25, 2018. https://sains.kompas.com/read/2018/05/04/200700623/kiprahsugeng-handoko-penggerak-di-balik-ekowisata-desa-nglanggeran?page=all.

Machendrawaty, Nanih dan Agus Ahmad Safei. Pengembangan Masyarakat Islam: dari Ideologi Strategi Sampai Tradisi. Bandung: Remaja Rosdakarya Bandung, 2001.

Pemerintah Desa Nglanggeran, Kecamatan Patuk, Kabupaten Gunungkidul Tahun 2013. "Profil Masyarakat Desa." Kalurahan Nglanggeran. July 6, 2020. https://www.nglanggeranpatuk.desa.id/first/artikel/34. 
Ratnasari, Elise Dwi. "Kisah Sugeng Handoko, 'Pejuang Air' Gunung Kidul." CNN Indonesia. May, 2018. https://www.cnnindonesia.com/gaya-hidup/20180507101350-282-296195/kisah-sugenghandoko-pejuang-air-gunung-kidul.

Soeharto, Edi. Membangun Masyarakat Memberdayakan Rakyat Kajian Strategis Pembangunan Kesejahteraan Sosial dan Pekerjaan Sosial. Bandung: Refika Aditama, 2014

Sudjatmiko, Tomi. "Siapkan Wisata Spa, Terapis Desa Wisata Nglanggeran Mendapat Pelatihan." krjogja.com. August

2017. https://krjogja.com/web/news/read/40829/Siapkan Spa Terapis Desa Wisata Nglanggeran Me ndapat Pelatihan.

Susilowati, Ellya. "Penerapan Teknologi Pengembangan Masyarakat Pada Program Desa Sabilulungan." LINDAYASOS: Jurnal Ilmiah Perlindungan \& Pemberdayaan Sosial vol. 1, no. 1 (2019): 16-31. http://jurnal.poltekesos.ac.id/index.php/lindayasos/article/view/170.

Wahyuni, Dinar. "Strategi Pemberdayaan Masyarakat Dalam Pengembangan Desa Wisata Nglanggeran." Aspirasi: Jurnal Masalah-Masalah Sosial vol. 9, no.1 (2018): 83-100. DOI: 10.46807/aspirasi.v9i1.994.

Warta Utama UAD. "Alumni FTI Ini Sukses Menggerakkan Masyarakat Sadar Akan Ekowisata Gunung Api Purba." Universitas Ahmad Dahlan. August 2, 2020. https://uad.ac.id/id/alumni-fti-ini-suksesmenggerakkan-masyarakat-sadar-akan-ekowisata-gunung-api-purba/

"BNI Taplus Bisnis Video Competition with Kumparan Griya Cokelat Nglanggeran." Video YouTube. 03:00. Dikirim oleh "Ifin Primandiri," April 6, 2018. https://youtu.be/dSL7sXoMKzw.

"Company Profile Griya Cokelat Nglanggeran." Video YouTube. 04:00. Dikirim oleh "Gunung Api Purba Nglanggeran," Agustus 20, 2017. https://youtu.be/890gz3Xlct4.

"DESA WISATA NGLANGGERAN MEMPEROLEH PEGHARGAAN CBT ASEAN DI SINGAPORE," GAP, 20 Januari $2017 . \quad$ http://gunungapipurba.com/posts/detail/desa-wisata-nglanggeran-memperolehpeghargaan-cbt-asean-di-singapore

"Indonesia Membangun Harmoni Gunung Api Purba Nglanggeran." Video YouTube. 24:39. Dikirim oleh "Gunung Api Purba Nglanggeran," April 26, 2016. https://www.YouTube.com/watch?v=YsdCn7MSEHw.

$\begin{array}{lllll}\text { "Informasi Geografis." } & \text { gunungapipurba.com. July } & 22, & \end{array}$ http://gunungapipurba.com/pages/detail/informasi-geografis.

"Inovasi Desa Wisata Nglanggeran: Mengamankan Pendapatan Desa Wisata Melalui Penerapan ETICKETING.” Video YouTube. 07:24. Dikirim oleh “Gunung Api Purba Nglanggeran,” Desember 27, 2017. https://www.YouTube.com/watch?v=ISyOPJszhJ0.

"Jumlah Wisatawan, Hotel dan Pariwisata." BPS Kabupaten Gunung Kidul. August 28, 2019. https://gunungkidulkab.bps.go.id/galery.html\#\#

"Kisah Sukses Griya Cokelat Nglanggeran Gunungkidul." Video YouTube. 02:24. Dikirim oleh "Gunung Api Purba Nglanggeran," Agustus 30, 2017. https://youtu.be/4 HI87BlvDQ.

“Pengembangan Agrowisata Gunungkidul, Gubernur Resmikan 'Griya Cokelat'," KabarHandayani: Jurnal Dinamika Gunungkidul (December 2016). http://kabarhandayani.com/pengembangan-agrowisatagunungkidul-gubernur-resmikan-griya-cokelat/.

“Pengembangan Wisata EcoSPA di Nglanggeran Gunung Kldul, Yogyakarta." Video YouTube. 12:06. Dikirim oleh “Lastiani Wulan," September 23, 2017. https://youtu.be/95yMMh3BKJ4.

"Statistik Berdasar Agama." Kalurahan Nglanggeran. Juli 6, 2020. https://www.nglanggeranpatuk.desa.id/first/statistik/agama. 
"Statisitik Berdasar Pendidikan." Kalurahan Nglanggeran. Juni 25, 2020. https://www.nglanggeranpatuk.desa.id/first/statistik/pendidikan-dalam-kk.

"Statistik Berdasar Pekerjaan." Kalurahan Nglanggeran. Juni 25, 2020. https://www.nglanggeranpatuk.desa.id/first/statistik/pekerjaan.

"Sosok Inspirasi, Sugeng Handoko Ubah Desa Tereksploitasi Menjadi Ekowisata." Gerakan Nasional Revolusi Mental. August 1, 2020. https://revolusimental.go.id/pers/sosok-inspirasi-sugeng-handoko-ubahdesa-tereksploitasi-menjadi-ekowisata.

"Sugeng Handoko: Peran Pemuda Membangun Desa-BukaTalks." Video YouTube. 20:29. Dikirim oleh

"Bukalapak." Juni 6, 2018. https://youtu.be/dxw0OTOG7k.

"Sugeng Handoko Pemberdayaan Pemuda dan Masyarakat Gunung Api Purba." Video YouTube. 18:26.

Dikirim oleh “Sugeng Handoko," November 10, 2014. https://youtu.be/YcPteZLHa1l.

“TTP Nglanggeran, Gunung Kidul, Yogyakarta, Jawa Tengah." Video YouTube. 03:50. Dikirim oleh "Likco Balingtan," Oktober 18, 2016. https://youtu.be/Setf4O 1Ois.

"Visi Misi dan Tujuan." gunungapipurba.com. August 10, 2019. http://gunungapipurba.com/pages/detail/visi-misi-dan-tujuan.

“Video Pemuda Pelopor_Sugeng Handoko.” Video YouTube, 9:22. Dikirim oleh “Sugeng Handoko.” October 16, 2011. https://youtu.be/jOVwHkESbpY.

"Wisata Edukasi: Waduk Nglanggeran Jogja-Obor Tani." Video YouTube. 04:57. Dikirim oleh "Film Obor Tani-IImu Tani-Agus Merdeka," November 8, 2017. https://youtu.be/IHy35nqznqc 